DOI https://doi.org/10.30525/978-9934-588-92-1-59

\title{
ФАКТОРИ, ЯКІ ОБУМОВЛЮЮТЬ СУЧАСНУ ПРОБЛЕМАТИКУ ВІДСУТНОСТІ МЕТОДОЛОГІЇ ДОСЛІДЖЕННЯ ПРАВОВОГО РЕГУЛЮВАННЯ ПОДАТКОВОЇ БЕЗПЕКИ УКРАЇНИ
}

\author{
Коломісць П. В. \\ кандидат юридичних наук, доиент, \\ доцент кафедри підприємництва і права \\ Полтавської державної аграрної академії \\ м. Полтава, Україна
}

Оскільки реалії сьогодення і досвід методології дослідження не містять «напрацьованої» моделі наукового пошуку правового регулювання податкової безпеки, то побудуємо нашу стратегію наукової розвідки починаючи з наступної аргументації факторів, які обумовлюють сучасну проблематику відсутності методології дослідження правового регулювання податкової безпеки України. Для виконання цього завдання, застосовуючи вже випробуваний і вивірений часом формально-юридичний метод наукового пізнання, проведемо аналіз концептуальних особливостей проблематики методології дослідження правового регулювання податкової безпеки України. Почнемо 3 найголовнішого, - правового регулювання суспільних відносин у сфері національної безпеки, оскільки податкова безпека $€$ складовою економічної безпеки, яка, у свою чергу, є однією із сфер національної безпеки [1].

Фактор перший - відсутність еволюиії правового регулювання податкової безпеки. Зауважимо, що починаючи зі здобуття незалежності, Україна має три нормативно-правові акти, які безпосередньо стосуються правового регулювання суспільних відносин у сфері національної безпеки, а саме: 1) Постанова Верховної Ради України від 16.01.1997 року № 3/97-ВР «Про Концепцію (основи державної політики) національної безпеки України» [1]; 2) Закон України від 19.06.2003 року № 964-IV «Про основи національної безпеки України» [2]; 3) Закон України від 21.06.2018 року № 2469-VIII «Про національну безпеку України» [3]. Проте, у жодному 3 цих нормативно-правових актів немає і згадки про правове регулювання податкової безпеки України. Складається враження, що про 
нормативне врегулювання суспільних відносин у сфері податкової безпеки України, за весь час незалежної України, воліли не згадувати.

Фактор другий - національні інтереси Украӥни та їх пріориmетність. Одним із основних принципів забезпечення національної безпеки $\epsilon$ адекватність заходів захисту національних інтересів реальним та потенційним загрозам. Національна безпека України досягається шляхом проведення виваженої державної політики відповідно до прийнятих доктрин, стратегій, концепцій і програм у таких сферах, як політична, економічна, соціальна, воєнна, екологічна, науково-технологічна, інформаційна тощо. Конкретні засоби і шляхи забезпечення національної безпеки України обумовлюються пріоритетністю національних інтересів, необхідністю своєчасного вжиття заходів, адекватних характеру i масштабам загроз цим інтересам, і грунтуються на засадах правової демократичної держави. Національні інтереси України відображають фундаментальні цінності та прагнення Українського народу, його потреби в гідних умовах життєдіяльності, а також цивілізовані шляхи їх створення і способи задоволення. Національні інтереси України та їх пріоритетність обумовлюються конкретною ситуацією, що складається в країні та за їі межами [1]. Проте, одразу ж наголосимо, що жоден із перелічених вище пріоритетів у сфері національної безпеки не можливо реалізувати без відповідного фінансового забезпечення, а бюджет держави Україна наповнюється, в першу чергу, податками. Економічні відносини у сфері податкової безпеки існують в незалежній Україні, проте ще не врегульовані нормою права. Тобто в Податковому кодексі України, що діє 31 січня 2011 року та регулює відносини у сфері оподаткування, досконалого правового регулювання податкової безпеки ще немає. Правове регулювання податкової безпеки не введено в національне законодавство, - поки що це поняття майже абстрактне, яке потрібно наповнювати нормативними вимірами. Отже, реалії сьогодення обумовлюють негайну потребу у законодавчому закріпленні податкової безпеки зі статусом надпріоритетності у сфері національних інтересів для усього суспільства і держави в цілому, тобто законодавець повинен поставити податкову безпеку на п'єдестал надпріоритетності у сфері національних інтересів, - раз і назавжди. Податкова безпека повинна бути першою серед рівних.

Фактор третій - відсутність мотивацї для наукових пошуків у сфері правового регулювання податкової безпеки. Результати проведеного аналізу перелічених вище нормативно-правових актів свідчать не тільки про факт відсутності правового регулювання сфери податкової безпеки, а ще й на відсутність мотивації для наукових 
пошуків у сфері правового регулювання податкової безпеки. Для аргументації цього фактору, який обумовлює сучасну проблематику відсутності методології дослідження правового регулювання податкової безпеки України, розглянемо Перелік наукових спеціальностей, затверджених наказом МОНмолодьспорту України від 14.09.2011 року № 1057 (далі - Перелік) [4], в якому установлено галузі наук, групи спеціальностей та наукові спеціальності за якими здійснюється підготовка наукових кадрів, проводяться захисти дисертацій на здобуття наукових ступенів кандидата наук і доктора наук, присуджуються наукові ступені. Почнемо 3 переліку наукових спеціальностей 3 економічної безпеки, як елементу національної безпеки (Таблиця 1).

Таблиця 1

\section{Перелік наукових спеціальностей з національної безпеки}

\begin{tabular}{|c|c|c|}
\hline Шифр & $\begin{array}{c}\text { Галузь науки, група } \\
\text { спеціальностей, спеціальність }\end{array}$ & $\begin{array}{c}\text { Галузь науки, за якою } \\
\text { присуджусться } \\
\text { науковий ступінь }\end{array}$ \\
\hline 21 & НАЦІОНАЛЬНА БЕЗПЕКА & \\
\hline 21.04 .00 & Економічна безпека & економічні \\
\hline 21.04 .02 & Економічна безпека держави & економічні \\
\hline
\end{tabular}

Джерело: складено автором за Переліком наукових спеціальностей [4].

Відповідно до формули спеціальності 21.04.01 - економічна безпека держави (економічні науки), що закріплена ії паспортом, затвердженим Постановою президії ВАК України від 15.12.2004 року (протокол № 11-10/11), - це галузь науки, яка досліджує національні економічні інтереси та загрози економічній безпеці України, здатність держави до захисту національних економічних інтересів від зовнішніх та внутрішніх загроз, а також здатності національної економіки зберігати та поновлювати процес суспільного відтворення і достатній оборонний потенціал у кризових ситуаціях. Встановлюючи напрямки досліджень, законодавець визначив і методологію дослідження проблем економічної безпеки. Разом з тим, фінансову безпеку та вплив на неї чинників фіскальної сфери та податкової політики, - законодавець закріпив як окрему сферу економічної безпеки. Крім того, тінізацію економіки як загрозу економічній безпеці і як напрямок досліджень, законодавець формулює через: форми та методи тінізації економічних відносин й економічної злочинності та засоби їх зменшення, проблеми тіньової 
зайнятості, засоби та методики легалізації тіньових доходів і капіталу, економічні аспекти поширення корупції та протидії ій (Таблиця 1) [5].

Відповідно до формули спеціальності 21.04.02 - економічна безпека суб’єктів господарської діяльності (економічні науки), що закріплена іiі паспортом, затвердженим Постановою президії ВАК України від 02.07.2008 року № 66-08/6, - це наукова спеціальність, що є сферою науки, яка досліджує: національну систему забезпечення економічної безпеки суб'єктів господарювання, діяльність яких впливає на стан економічної безпеки держави; теоретико-методологічні, науковометодичні та практичні засади організації, функціонування та розвитку систем економічної безпеки транснаціональних компаній, корпорацій, банків і підприємств; цілі, завдання, форми, методи, технології, механізми управління та взаємодії служб безпеки суб'єктів господарювання в системі економічної безпеки відповідно до вимог національних i міжнародних стандартів. Встановлюючи напрямки досліджень, законодавець також визначив і методологію дослідження систем економічної безпеки суб'єктів господарювання (Таблиця 1) [6].

Аналіз останніх наукових пошуків за спеціальностями 21.04.01 економічна безпека держави (економічні науки) та 21.04.02 економічна безпека суб'єктів господарської діяльності (економічні науки), показує, що в період з 2018 року до другої половини 2020 року було написано ряд дисертаційних досліджень на здобуття наукового ступеня доктора економічних наук, в яких науковцями обгрунтовується різні підходи до вибору науково-методологічної бази їх досліджень.

\section{Література:}

1. Про Концепцію (основи державної політики) національної безпеки України: Постанова Верховної Ради України від 16.01.1997 р. № 3/97-ВР. Відомості Верховної Ради України. 1997. № 10. Ст. 85.

2. Про основи національної безпеки України: Закон України від 19.06.2003 р. № 964-IV. Відомості Верховної Ради України. 2003. № 39. Ст. 351.

3. Про національну безпеку України: Закон України від 21.06.2018 р. № 2469-VIII. Відомості Верховної Ради Украӥни. 2018. № 31. Ст. 241.

4. Про затвердження Переліку наукових спеціальностей: Наказ МОНмолодьспорту України від 14.09.2011 р. № 1057. Офіuійиий вісник України. 2011. № 78. Ст. 2893.

5. Паспорт спеціальності 21.04.01 - економічна безпека держави (економічні науки): Постанова президії ВАК України від 15.12.2004 p. 
протокол № 11-10/11т. Бюлетень Вищої атестаційної комісії України. 2005. № 4.

6. Паспорт спеціальності 21.04.02 - економічна безпека суб'єктів господарської діяльності (економічні науки): Постанова президії ВАК України від 02.07.2008 р. № 66-08/6. Бюлетень Вищої атестаційної комісї Украӥни. 2008. № 12.

DOI https://doi.org/10.30525/978-9934-588-92-1-60

\title{
«МАРКЕРИ» ДЕФЕКТНОСТІ «ЯКОСТІ» ЗАКОНОДАВЧОГО ВРЕГУЛЮВАННЯ МОНІТОРИНГУ СПОСОБУ ЖИТТЯ ПУБЛІЧНОГО СЛУЖБОВЦЯ ЯК ПЕРЕДУМОВИ ЗНЕЦІНЕННЯ АНТИКОРУПЦІЙНОГО ЗАСОБУ
}

\author{
Коломоєць Т. $\mathbf{O}$. \\ доктор юридичних наук, професор, \\ член-кореспондент Національної академії правових наук України, \\ заслужений юрист України, \\ декан юридичного факультету \\ Запорізького національного університету \\ м. Запоріжжя, Україна
}

Перегляд основних векторів запобігання корупції у всіх іiі проявах в Україні безпосередньо пов'язаний із з'ясуванням реального ресурсу кожного засобу такого запобігання у системі інструментарію останнього із обов'язковим грунтовним аналізом їх законодавчих засад. Серед всього розмаїття таких засобів своє чільне місце завжди посідав й зберігає до цього часу, завдяки особливості свого ресурсу, цільовій спрямованості, моніторинг способу життя публічних службовців, засади якого унормовані, насамперед, у ст. 51 Закону України «Про запобігання корупції» та підзаконних нормативно-правових актах. Україна не $\epsilon$ унікальною у запровадженні цього антикорупційного засобу, практика активного його використання вже сформована у багатьох країнах світу, інше питання - чи $є$ ця практика позитивною у запобіганні корупції і чи дієвою $є$ модель, закріплена у законодавстві України? Аналіз законодавства зарубіжних країн свідчить про те, що в наявності ефективне використання моніторингу у Філіппінах, Сінгапурі. Румунії. Руанді, Монголії тощо. При цьому різними є моделі 